\title{
Physiological Reasons for Attractiveness of Female Breast
}

\author{
K. P. Skandhan \\ Department of Physiology, Sree Narayana Institute of Medical Sciences, Chalakka, India \\ Email: kpskandhan@gmail.com
}

Received 29 November 2013; revised 29 December 2013; accepted 6 January 2014

Copyright (C) 2014 by author and Scientific Research Publishing Inc.

This work is licensed under the Creative Commons Attribution International License (CC BY).

http://creativecommons.org/licenses/by/4.0/

(c) (i) Open Access

\begin{abstract}
In this article the possibilities of functioning of breast as an attractant to male and leading to a long lasting relation in many cases are discussed. The three mechanisms discussed are on the basis of visual stimuli, pheromone and other chemicals like sebum.
\end{abstract}

\section{Keywords}

Breast, Attractive, Pheromone, Semiochemical, Visual Stimuli

\section{Discussion}

The Hindu mythology, Ramayana, occasionally showed female breasts as an attractant. Lord Rama (whose glory is narrated in Ramayana) ordered to excise the breasts of Soorpanakha, who thronged to love His brother Laxmana. By this action probably Lord consoled himself by making the woman unattractive. All over the world, the fleshy female breasts are prominently figured in sculpture, canvas, prose and verse. Credulously, these are examples showing breast of woman as attractive to men. Many times in reality, such drawings occupy attention and end in everlasting bond [1]. In all cultures men manipulated manually (98\%) and orally (93\%) the breast of their partners [2]. It was rare in vice versa situation. Kinsey and associates [3] wondered over the biologically based mechanisms responsible for this attraction. We explain the three possible mechanisms for it as 1) male instinct for hidden organ (visual) 2) action of secretory products of apocrine glands and 3) sebaceous glands present on breast.

\section{Visual Stimuli and Response}

World wide exposure of woman's breast is considered as obscene. So this greatly and prominently projected portion of the body, is always well dressed and hidden. The size and shape of breast remained attractable and 
functioned fetish to many. It must be true, 1) Men blind from birth have no instinct of women’s breasts unless had physical contact (we have no available literature on this and 2) women have no special attraction to male breast [2] [3].

Psychological phenomenon "attraction of unavailability" explained the multiplying nature of the inquisitiveness to any hidden object. It is known as the prime reason for attraction to hidden breast; the root cause in man's nearness to female breast. This is supported by the fact that 1 ) in a tribal community where women do not cover their chest, neither their men paid special attention nor the exposed portion caused any sexual arousal in male [2] or 2) on several occasions exposure of breast for feeding baby terminated in incest [4]. Many times the curiosity multiplied in man with a short spell of contact, usually accidental touch with the organ revealing the texture from soft to firm. The sensation of touch stored in memory further develops nearness to the organ.

\section{Role of Aprocrine Glands}

The pheromone is a chemical substance secreted by an animal which stimulates one of the behaviours of other animals of the same species. In many cases it acts as a sex attractant or a stimulant. The existence of a pheromone in man is not established. The debate continues and evidences mount in support of it [5]-[15].

Results from animal studies promulgated apocrine glands as the likely source of pheromone in man. These glands are located mainly in axillary and pubic regions. They are regarded as vestigial remains. They lie docile till puberty indicating sex hormones are involved in making them active and indicating its possible role in reproductive life. They become less active in old age. The secretion of these glands is emptied to pilosebaceous follicle above the entrance of the sebaceous duct in the infundibulum. The release of the secretion is regular. It is usually colourless, milky or of any different colours; but odourless. It gives typical "human adult smell" when decomposed by bacteria. Biologists considered the hair present in axilla and pubic regions helped to spread the secretion of aprocrine glands, pheromone, to surrounding atmosphere to attract the opposite sex [16].

In female breast, apocrine glands are abundant in areola [17] and on nipple [18]. The glands of Montgomery present as small elevations in areola are also aprocrine glands [17]. Surrounding the nipple on areola small hairs are present [19] which are absent on nipple [18]. In absence of hairs also through follicular opening aprocrine secretion is given out. Some of their ducts open directly outside the skin [20]. Skin of the breast is thin and has hair follicles, sebaceous glands and eccrine glands [18]. The results of different biological studies permit us to believe that human female breast liberate pheromone to attract men. Study of Varendi et al. [21] proved that newborn baby finds mothers nipple by smell probably through pheromone emitted by this region. This was supported by several others [13]. During lactating period woman attracts opposite sex [13], sometimes ending is incest (Sibony, 1989) and in her company increases sexual activity in other women [12].

The product of the gland is propelled out by waves of peristalsis present on myoepithelaial cells placed in a longitudinal layer outside the gland [20]. Possibly there are two extra mechanisms involved in extrusion from breast. These glands are largely supplied by adrenergic sympathetic nerves and are also stimulated by circulating epinephrine [20]. During sexual excitation sympathetic nerves are stimulated and this leads to release of more pheromone. Thus during petting or sexual arousal in women, the circulating adrenergic hormones must be continuing to keep male partner aroused through pheromone. Secondly, "sex flush" causing wavular feelings on breast may be responsible for releasing more pheromone which further leads to attract male partner.

\section{Role of Sebaceous Glands}

Mouth breast contact constitutes the one technique in human petting behaviour which is most distinctly human [2]. Physiological reasonings on this kind of oral eroticism are known. Mouth is an erogenous zone richly supplied with end organs of touch. Filling mouth with breast, contented one's sexual desire through tactile sensation and to some degree it caused erotic arousal [2].

Nicholson hypothesized kissing as for strengthening human bond [22]. He explained the mechanism as recognition of chemical action of sebum which enters the mouth of the one who kisses. The action of sucking promotes the entry of sebum into buccal cavity. Considering this theory in current discussion, sebaceous glands are many in areola conveying sebum to the skin through hair follicles. Sebum flows freely when body is warm. During sexual activity the rise in body temperature may increase flow of sebum. Summarily sucking the breast permitting an addiction through chemical recognition of sebum and leading to a long lasting human bond [22]. 


\section{Conclusion}

Female breast remains attractive and sexual stimulant to man. Three mechanisms are explained in terms of "attraction of unavailablity”, and the physiological roles played by pheromones and sebum. Many times attractant breast functions as a medium for an everlasting relation.

\section{References}

[1] Kirchoff, H. (1990) Die Kunsterische duestelong der weiblichen brestals attrribut der weiblichkeit and fruchbarkent alsa suchdev spender lebuskraft under weighit. Geburtshifte Frameee, 50, 234-243. http://dx.doi.org/10.1055/s-2007-1026471

[2] Kinsey, A.C., Pomeroy, W.B. and Martin, C.E. (1953) Sexual Behaviour in Human Male. WB Saunders Company, Philadelphia.

[3] Kinsey, A.C., Pomeroy, W.B., Martin, C.E. and Gebard, P.H. (1953) Sexual Behavior in the Human Female. WB Saunders Company, Philadelphia.

[4] Sibony, D. (1989) Lesein a vion, Le sein boire: Quesein se vouer? Contracept Fertal Sex, 19, 375-380.

[5] Benton, D. (1982) The Influence of Androstenol-A Putative Human Pheromone on Mood throughout the Menstrual Cycle. Biological Psychology, 15, 249-256. http://dx.doi.org/10.1016/0301-0511(82)90047-3

[6] Burger, J. (1985) A Hypothesis on the Role of Pheromones on Age of Menarche. Medical Hypotheses, 17, 29-46. http://dx.doi.org/10.1016/0306-9877(85)90018-0

[7] Doty, R.L., Ford, M., Preti, G. and Huggins, G.R. (1975) Changes in the Intensity and Pleasentness of Human Vaginal Orders during the Menstrual Cycle. Science, 190, 1316-1318. http://dx.doi.org/10.1126/science.1239080

[8] Mc Clintock, M.K. (1969) Menstrual Synchrony and Suppression. Nature, 229, 224-245.

[9] Skandhan, K.P., Pandya, A.K., Skandhan, S. and Mehta, Y.B. (1975) Synchronisation of Menstrual Cycles among Kins and Kindreds. Panminerva Medicine, 21, 131-135.

[10] Skandhan, K.P., Amith, S., Vadedarua, H., Mazumdar, B.N., Dhuri, K. and Gondalia, H. (2013) Pheromones in Human Urine. A Study. Advanced Sex Medicine, 3, 25-28.

[11] Skandhan, K.P., Kaoru, O., Mukund, B.M. and Sumangala, B. (2013) Place of Pheromone in Rape. Advanced Sex Medicine, 3, 24-27. http://dx.doi.org/10.4236/asm.2013.31005

[12] Spencer, N.A., McClintock, M.K., Sellergen, S.A., Bullivant, S., Jacob, S. and Mennella, J.A. (2004) Social Chemosignals from Breast Feeding Women Increase Sexual Motivation. Hormones and Behavior, 48, 362-370. http://dx.doi.org/10.1016/j.yhbeh.2004.06.002

[13] Vagio, S. (2009) Chemical Communication and Mother Infant Recognition. Communication in International Biology, 2, 279-281. http://dx.doi.org/10.4161/cib.2.3.8227

[14] Veith, J.L., Buck, M. and Getzalf, S. (1983) Exposure to Men Influences the Occurrence of Ovulation in Women. Physiological Behaviour, 31, 313-315. http://dx.doi.org/10.1016/0031-9384(83)90194-4

[15] Wilson, A.C. (1988) Male Axillary Secretions Influence Women’s Menstrual Cycles. A Critique. Hormones and Behavior, 22, 226-271.

[16] Burton, R. (1976) The Language of Smell. Routledge and Kegan Paul, London.

[17] Ellis, R.A. (1967) Eccrine, Sebaceous and Aprocrine Glands. In: Zelikon, A.S., Ed., Ultrastructure of Normal and Abnormal Skin, Lea and Febiger, Philadelphia.

[18] Michael, P.O. and Susan, K.B. (2010) Breast Anatomy and Development. In: Harris, P.R., Lippman, M.E., Morrow, M. and Osborn, C.K., Eds., Diseases of the Breast, Chapter 1, Lippincott Willianms and Wilkins, Philadelphia.

[19] Kothari, P. (1987) Common Sexual Problems Solutions. VRP Publisher, Bombay.

[20] Rook, A., Wilkinson, D.S. and Ebling, F.I.G. (1992) The Text Book of Dermatology. Blackwell Scientific Publications, Oxford.

[21] Varendi, H., Porter, R.H. and Winberg, J. (1994) Does the New Born Find the Nipple by Smell? Lancet, 344, 989-990. http://dx.doi.org/10.1016/S0140-6736(94)91645-4

[22] Nicholson, B. (1984) Does Kissing Aid Human Bonding by Semiochemical Addiction? (Comment) British Journal of Dermatology, 111, 623-627. http://dx.doi.org/10.1111/j.1365-2133.1984.tb06635.x 